\title{
ANALISIS DAN PENERAPAN SASARAN KESELAMATAN PASIEN
}

\section{RUMAH SAKIT}

\author{
Friderikus Zebua \\ zebuafriderikus@gmail.com
}

\section{LATAR BELAKANG}

Isu keselamatan pasien melahirkan paradigma baru tentang mutu pelayanan. Mutu pelayanan yang baik saja tidak cukup berarti bagi pasien tanpa memperhatikan bagaimana derajat unsur resiko dan keselamatan yang diterima oleh pasien. Tinggi rendahnya mutu sebanding dengan tingkat ketersediaan fasilitas pelayanan, untuk mencapai keseimbangan terbaik antara risiko dan manfaat keselamatan yang diterima oleh pasien.

Keselamatan pasien menjadi masalah yang cukup menjadi perbincangan di dunia. Keselamatan pasien kemudian dikembangkan baik itu langkah - langkah mewujudkan keselamatan pasien dan juga bentuk sasaran apa yang menjadi pertimbangan untuk di perhatikan. Sasaran keselamatan pasien disini adalah apa yang menjadi goals atau target untuk mengatasi Kejadian Tidak Terduga, bukan mengenai siapa yang menjadi sasaran tentu yang menjadi sasaran nya adalah pasien. Tetapi setiap pasien mempunyai asuhan keperawatan yang berbeda.

Sasaran Keselamatan Pasien adalah mendorong peningkatan spesifik dalam keselamatan pasien. Sasaran ini menyoroti area yang bermasalah dalam pelayanan kesehatan dan menguraikan tentang solusi atas konsensus berbasis bukti dan keahlian terhadap permasalahan ini. Sasaran Keselamatan Pasien (SKP) menjadi indikator standar dasar yang utama dalam penilaian Akreditasi Rumah Sakit versi 2012 (KARS, 2013). Sasaran Keselamatan Pasien merupakan suatu bagian dari Standar Akreditasi Rumah Sakit yang harus dapat diterapkan di rumah sakit yang berguna dalam meningkatkan pelayanan kesehatan yang berkualitas (Diah dkk, 2015)

Maksud dari sasaran keselamatan pasien adalah mendorong perbaikan spesifik dalam keselamatan pasien yang menyoroti bidang-bidang bermasalah dalam perawatan kesehatan, memberikan bukti dan solusi hasil konsensus yang berdasarkan nasihat para pakar. Untuk 
menerapkan terwujudnya sasaran keselamatan pasien ini perlu pengetahuan dan motivasi dari perawat juga tentunya menjadi faktor pendorong terwujudnya pelaksanaan sasaran keselamatan pasien (Diah dkk, 2015)

\section{METODE}

Jurnal ini menggunakan metode tersearch dan analisis dari berbagai sumber seperti buku teks, buku referensi jurnal, Tesis, Buku, majalah, Koran dan juga membandingkan beberapa

jurnal yang berhubungan dengan tujuan dan kriteria perencanaan asuhan keperawatan di rumah sakit. Dari analisi berbagai sumber digunakan Untuk mengetahui Indikasi penerapan sasaran keselamatan pasien di rumah sakit. Jurnal yang saya ambil adalah jurnal yg di terbitkan 10 tahun terakhir yang terdiri dari sepuluh sumber.

\section{HASIL}

Terdapat 6 sasaran keselamatan pasien yaitu meliputi : : 1) ketepatan identifikasi pasien; 2) peningkatan komunikasi yang efektif; 3) peningkatankeamanan obat-obatan yang harus diwaspadai; 4) kepastian lokasi pembedahan yang benar, prosedur yang benar dan pembedahan pada pasien yang benar; 5) pengurangan risiko infeksi terkait pelayanan kesehatan; 6) pengurangan risiko cedera pasien akibatterjatuh. Akan kita observasi dari berbagai jurnal.

1. Ketepatan Identifikasi Pasien. Lebih dari setengah perawat telah menerapkan kebijakan atau prosedur dalam mengidentifikasi pasien. Namun masih ada perawat yang hanya menggunakan nomor kamar atau nomor tempat tidur saja ketika melakukan identifikasi

2. Komunikasi efektif. Saat perawat bertanya kepada dokter, perawat menyiapkan kertas untuk mencatat instruksi dokter dan mengkonfirmasi ulang apa yang sudah dicatat oleh perawat dan begitu pun dengan lisan. Ketika ada tulisan dokter yang tidak terbaca, perawat mengkonfirmasi ulang dengan dokter. Komunikasi perawat dengan pasien juga baik, saat melaukan suatu tindakan, perawat menjelaskan prosedur layanan kesehatan dari awal kepada pasien dan juga melakukan tindakan pemberian informed consent kepada pasien untuk persetujuan tindakan 
3. Keamanan obat dan cairan. Perawat melakukan 8 benar dalam menunjang

keselamtan pasien seperti : benar obat, benar dosis, benar waktu, benar cara, benar dokumentasi, benar informasi, dan benar pengkajian. Obat - obatan juga berada diabwah pengawasan apoteker, sehingga jika ada obat yang memiliki dosis tinggi,maka perawat akan menanyakan kembali kepada dokter.

4. kepastian lokasi pembedahan yang benar, prosedur yang benar dan pembedahan pada pasien yang benar. Sebagian besar perawat telah melakukan upaya untuk peningkatan ketepatan lokasi, prosedur dan pasien operasi, sebelum dilakukan operasi kepasien, antara lain melakukan pengecekan identitas, menegcek prosedur dan lokasi operasi, melakukan prosedur rutin seperti enema sesuai instruksi dokter, menganjurkan pasien, menyiapkan dan mengecek hasilfoto rontgen dan hasil pemeriksaan lainnya

5. pengurangan risiko infeksi terkait pelayanan kesehatan. Sebagian besar perawat telah menerapkan tindakan untuk mengurangi infeksi dengan mencuci tangan. sebelum dan sesudah melakukan tindakan keperawatan. Dan disetiap depan kamar pasien terdapat desinfektan.

6. Pengurangan risiko cedera pasien akibat terjatuh. Lebih dari setengah perawat telah melakukan usaha pencegahan jatuh dengan menaikkan pengaman atau pembatas tempat tidur dan menganjurkan pasien untuk memencet bel jika memerlukan bantuan . selain itu, perawat juga memberikan label pada tangan pasien untuk mengetahui bahwa pasien tersebut adalah pasien dengan resiko jatuh.

\section{PEMBAHASAN}

Sasaran Keselamatan pasien (SKP) yang pertama yaitu identifikasi pasien . SKP pertama yaitu rumah sakit mengembangkan sistem identikasi pasien. Salah satu penilain SKP adalah pasien diidentifikasi menggunakan dua identitas pasien, tidak boleh menggunakan nomor kamar atau lokasi. Setelah dilakukan brainstorming disepakati bahwa pasien diidentifikasi dengan menggunakan dua identitas dan nomor rekam medis, yaitu menggunakan nama dan alamat. 
Pemberian gelang tangan (wristband) dlengan, kaki atau tangan menjadi prosedur utama bagi pemberian identitas pasien, terutama bagi pasien yang akn diberikan tindakan invasive, pembedahan, pemberian tranfusi, pemeriksaan imaging, atau pasien yang tidak sadar.

Ketentuan gelang tangan antara lain adalah:

1. Harus ditulis dengan menggunakan huruf balok,

2. Penulisan secara jelas dan tidak luntur apabila terkena air,

3. Harus mencakup paling sedikit dua dari identitas pasien, nama, tanggal lahir, usia, jenis kelamin, ataupun nomor register rekam medis.

Meskipun ketentuan penulisan identitas pasien pada gelang sudah dilakukan, ukan berarti gelang identitas menjadi satu-satunya cara untuk dapat mencegah kesalahan identikasi pasien. Di Australia selatan semua pasien harus diidentifikasi dengan benar dan sesuai dengan asuhannya untuk menghindari resiko ketidaksesuaian dan mereduksi kerugian pasien. Sangat penting untuk mengidentikasi pasien dengan benar sebelum elakukan pelayanan asuhan kesehatan. Paling tidak terdapat 3 identitas pasien meliputi nama, tanggal lahir dan nomor rekam medis. Semua master indeks pasien baik manual ataupun elektronik serta rekam medis harus memiliki 3 identitas pasien meliputi nama, tanggal lahir, dan nomor rekam medis . sistem berkode yang digunakan pada proses identifikasi pasien harus terhubung dengan informasi 3 identitas pasien tersebut dalam master indeks pasien elektronik.

Penyebab terjadinya kesalahan identfikasi pasien dikategorikan menjadi 3 hal yaitu:

1. Kesalahan penuisan dan administrasi,

2. Kesalahan dalam verifikasi,

\section{Problem komunikasi.}

Kesalahan dalam penulisan dan adminitrasi dikelompokkan pada kesalahan dalam labeling, kesalahan dala pengisian data, kesalahan dalam penulisan angka berdigit dan pendokumentasian yang tidak lengkap. Kesalahan dalam verifikasi bisa terjadi pada prosedur verifikasi yang tidak ada dan tidak dilakukan. Hambatan komunikasi yang sering terjadi adalah hambatan bahasa, 
kondisi pasien dan kegagalan dalam serah terima alih tugas. Ketidakselarasan dalam komunikasi yang dilakukan oleh perawat kepada pasien bisa meningkatkan kejadian yang tidak diinginkan (KTD) sehingga keselamatan pasien tidak tercapai. Selama perawatan kebutuhan pasien dapat terpenuhi apabila ditunjang dengan kelengkapan komunikasi informasi yang diberikan dan berhubungan dengan identitas resiko keselamatan.

Dari uraian diatas, faktor utama untuk mencegah terjadinya kesalahan identifikasi pasien adalah ketersediaan dan kepatuhan terhadap SPO dan pelaporan apabila terjadi kesalahan identifikasi pasien. Pelaporan kesalahan identifikasi pasien perlu sebagai dasar perbaikan SPO dan pembelajaran agar tidak terjadi lagi kesalahan identifikasi pasien. Beberapa manfaat yang dapat di peroleh apabila semua tindakan didasarkan pada kebijakan dan prosedur yang telah di tetapkan antara lain: keseragaman dan konsistensi tata kelola, kejelasan terhadap tugas yang dibebankan, mengurangi kesalahan dalam tindakan, menciptakan efisiensi waktu dan biaya, menetapkan pertanggungjawaban dari setiap tindakan, mempermudah menentukan pelatihan, menyiapkan kebijakan dan prosedur yang baru.

Analisis Sasaran Keselamatan Pasien terdiri dari :

- Analisis Sumber daya, Dalam menganalisis sumber daya manusia dalam penelitian ini dilihat dari dua kriteria, yaitu kualitas dan kuantitas tenaga yang terlibat.

- Analisis Kebijakan dan SOP, Kebijakan dan SOP dalam penelitian ini adalah ketersediaan kebijakan, peraturan, SOP, atau pedoman tentang sasaran keselamatan pasien khususnya pelaksanaan identifikasi pasien dan keamanan obat di RSPAD Gatot Soebroto.

- Analisis Sarana dan Prasarana . Sarana dan prasarana keselamatan pasien khususnya identifikasi pasien dan menjaga keamanan obat telah tersedia dan tercukupi.

- Analisis Pengorganisasian, Terdapat struktur organisasi keselamatan pasien di rumah sakit, struktur organisasi tersebut di tempelkan di dinding di ruang komite mutu dan keselamatan pasien, serta di bagian unit rawat inap. 
- Analisis Pelaksanaan Kebijakan dan SOP Identifikasi Pasien dan Keamanan Obat. Pelaksanaan kebijakan dan SOP yaitu kesesuaian atau tidaknya pelaksanaan identifikasi pasien dan terlabelnya obat high alert dengan kebijakan dan SOP.

- Analisis Komitmen Petugas. Komitmen petugas merupakan adanya sikap kesediaan yang berasal dari petugas yang dalam hal ini yaitu perawat dan tim keselamatan pasien rumah sakit untuk melaksanakan aturan yang ada di rumah sakit dalam melaksanakan tugasnya.

- Analisis Pelaporan Pelaporan insiden keselamatan pasien yang selanjutnya disebut pelaporan insiden adalah suatu sistem untuk mendokumentasikan laporan insiden keselamatan pasien, analisis dan solusi untuk pembelajaran.

\section{PENUTUP}

Penerapan sasaran keselamatan pasien (SKP) di rumah sakit yang paling utama yaitu identifikasi pasien. Pemberian gelang tangan (wristband) di lengan, kaki atau tangan menjadi prosedur utama bagi pemberian identitas pasien. faktor utama untuk mencegah terjadinya kesalahan identifikasi pasien adalah ketersediaan dan kepatuhan terhadap SPO dan pelaporan apabila terjadi kesalahan identifikasi pasien. pasien. Apabila prosedur identifikasi pasien dilaksanakan dengan benar maka akan mencegah kesalahan dalam melaksanakan proses pelayanan kesehatan.

\section{DAFTAR PUSTAKA}

Arum, D., Salbiah., \& Manik, M. 2015. Pengetahuan Tenaga Kesehatan dalam Sasaran Keselamatan Pasien di Rumah Sakit Sumatera Utara. Idea Nursing Journal, 7(2), 1-6.

Harsul, W., Syahrul, S \& Majid, A. 2018. Penerapan Budaya Pelaporan Insiden Keselamatan Pasien di Rumah Sakit Umum Daerah Tipe B Provinsi Sulawesi Selatan. Jurnal Parinta Abdi, 2(2), 119-126. 
Harus, B.D., Sutriningsih, A. 2015. Pengetahuan Perawat Tentang Keselamatan Pasien dengan Prosedur Keselamatan Pasien di Rumah Sakit.(KPRS) di Rumah Sakit Panti Waluya Sawahan Malang. Jurnal Care, 3(1), 25-32.

Keles AW, Kandou GD, Tilaar CR. Analisis Pelaksanaan Standar Sasaran Keselamatan Pasien di UGD RSUD Dr. Sam Ratulangi Tondano Sesuai Dengan Akreditasi RS Versi 2012. Manado. Universitas Sam Ratulangi. Jurnal Ilmu Kesehatan Masyarakat Unsrat (JIKMU). 5(3):250-259. [diakses 12 Januari 2018]

Lombogia A, Julia R, Michael K. Hubungan Perilaku dengan Kemampuan Perawat dalam Melaksanakan Keselamatan Pasien (Patient safety) di Ruang Akut Instalasi Gawat Darurat RSUP Prof. Dr. R. D. Kandou Manado. E $\square$ journal Keperawatan (e-Kp). 4(2):1-8. [diakses 12 Januari 2018].

Reno, dkk. (2018). Analisis Pelaksanaan Sasaran Keselamatan Pasien di Ruang Rawat Inap Rumah Sakit Umum Daerah Padang Pariaman. Jurnal Kesehatan Andalas; 7

Sanjaya P D, Elsye M R, Maria U. Evaluasi Penerapan Pencegahan Pasien Berisiko Jatuh di Rumah Sakit. Jurnal Kesehatan Masyarakat. 11(2):105-113. [diakses 28 Juli 2018].

Sakinah, s. dkk. (2017).Analisis sasaran Keselamatan pasien dilihat dari aspek pelaksanaan identifikasi pasien dan keamanan Obat di RS Kepresidenan RSPAD gatot Soebroto. Jakarta .Journal Kesmas , 5. (4)

Simamora, R. H. (2018). Buku ajar keselamatan pasien melalui timbang terima pasien berbasis komunikasi efektif: SBAR. Medan: USUpress.

Simamora, R. H. (2020). Learning of Patient Identification in Patient Safety Programs Through Clinical Preceptor Models. Medico Legal Update, 20(3), 553-556.

Sundoro. Evaluasi Pelaksanaan Sasaran Keselamatan Pasien Sesuai Akreditasi Rumah Sakit Versi 2012 di Rumah Sakit Khusus Ibu Dan Anak PKU Muhammadiyah Kotagede Yogyakarta. Jurnal Medicoeticolegal dan Manajemen Rumah Sakit, 5(1):40-48. [diakses 28 Juli 2018] 
Tutiany, Lindawati \& Paula. (2017). Bahan Ajaran Keperawatan : Manajemen Keselamatan Pasien.Kementerian Kesehatan RI.

Widiasari, dkk. (2019). Kepuasan Pasien Terhadap Penerapan Keselamatan Pasien Di Rumah Sakit. Jurnal Keperawatan Indonesia, 22 (1), 43 - 52. 